\title{
The evaluation of aortic elasticity in subclinical hypothyroidism
}

\author{
Subklinik hipotiroidide aort elastisitesinin değerlendirilmesi
}

Sevil ÖZKAN. Dursun DUMAN. Mehmet Ali TARIM. Refik DEMIRTUNÇ

\section{ABSTRACT}

Objective: In this study we evaluated the elastic properties of the aorta in patients with subclinical hypothyroidism and their relation with left ventricular diastolic function by transthoracic echocardiography.

Patients and Methods: Aortic transthoracic echocardiography was performed and the aortic elasticity was evaluated using the following parameters; strain, the beta index and distensibility.

Results: There was significant difference in terms of aortic strain $(5.79 \%$ vs. $9.45 \% \mathrm{p}<0.001)$ and distensibility (4.64 versus $3.0210-3 . \mathrm{cm} 2$. dyn-1. $\mathrm{p}<0.005)$ between the control group and patients with subclinical hypothyroidism group. In the subclinical hypothyroidism group the average mitral early diastolic velocity (E). $(\mathrm{p}<0.05)$ were significantly lower than the mean mitral diastolic flow velocity / mitral late diastolic flow velocity (E / A) $(\mathrm{p}<0.01)$ observed in the control group. and higher than the mean mitral late diastolic flow velocity (A) and isovolumetric relaxation time (IVRT) $(\mathrm{P}<0.05)$ in the control group.

Conclusions: In patients with subclinical hypothyroidism an increase in the aortic stiffness was observed. The diastolic dysfunction observed in subclinical hypothyroidism is mainly responsible for the increase in the aortic stiffness.

Keywords: Aortic stiffness. Subclinical hypothyroidism. Left ventricular diastolic dysfunction

Sevil Özkan (四). Mehmet Ali Tarım. Refik Demirtunç

Internal Medicine Clinic. Istanbul Haydarpasa Numune Training and Research Hospital. Istanbul. Turkey

e-mail:sevilfurkan@hotmail.com

Dursun Duman

Department of Cardiology. School of Medicine. Istanbul Medipol University. İstanbul. Turkey

Submitted/Gönderilme: 16.05.2015 Accepted/Kabul: 01.09.2015

\section{ÖZET}

Amaç: $\mathrm{Bu}$ çalışmada. subklinik hipotiroidili hastalarda aortun elastikiyet özellikleri ve bunların sol ventrikül diyastolik fonksiyonu ile ilişkileri transtorasik ekokardiyografik metod ile araştırıldı.

Hastalar ve Yöntemler: Transtorasik ekokardiyografi yapilarak aortun elastikiyet parametreleri olarak aortik strain. beta indeksi ve distensibilite indeksine bakıld1.

Bulgular: Kontrol grubu ve subklinik hipotiroidili hasta grubu arasında aortik strain (sırasıyla \%9.45'e karşı \%5.79. p<0.001) ve distensibilite (4.64'e karş1 3.02 10-3.cm2.dyn-1. $\mathrm{p}<0.005$ ) yönünden anlamlı farklar vard1. Subklinik hipotiroidi grubunda mitral erken diyastolik akım hızı $(E)$ ortalamas $(p<0.05)$. mitral diyastolik akım hızı/ mitral geç diyastolik akım hızı (E/A) $(\mathrm{p}<0.01)$ kontrol grubu ortalamasına göre anlamlı olarak düşük. mitral geç diyastolik akım hızı ortalaması (A) ve izovolümetrik relaksasyon zamanı ( IVRZ) $(\mathrm{p}<0.05)$ kontrol grubu ortalamasına göre yüksek bulundu.

Sonuç: Subklinik hipotiroidili hastalarda aortik stiffness'de artış gözlenmektedir. Subklinik hipotiroidili hastalarda gözlenen diyastolik fonksiyon bozukluğundan esas olarak aortik stiffness artışı sorumlu olabilir.

Anahtar kelimeler: Aortik stiffness. Subklinik hipotiroidizm. Sol ventrikül diyastolik disfonksiyonu

\section{Introduction}

Subclinical hypothyroidism ( $\mathrm{SCH}$ ) is defined as thyroid dysfunction consisting of normal serum thyroid hormone levels and high thyroid stimulating hormone (TSH) [1.2]. The frequency of SCH varies between $4-10 \%$. and incidence increases with age [3]. Chronic autoimmune thyroiditis (Hashimoto's thyroiditis) has been identified in the etiology of $55 \%$ of $\mathrm{SCH}$ cases. Other common causes include thyroid ablation with radioactive iodine. partial 
thyroidectomy. antithyroid drugs. and external radiotherapy. drugs such as amiodarone and lithium. radiocontrast agents. insufficient thyroid hormone replacement therapy in overt hypothyroidism [4]. Several epidemiological studies have reported that $\mathrm{SCH}$ may be a cardiovascular risk factor and increase the risk of aortic atherosclerosis and myocardial infarctions [5]. While some studies [5-7] have determined a relationship between $\mathrm{SCH}$ and coronary artery disease. other studies [8.9] have failed to do so.

Aortic stiffness (aortic stiffness) represents the mechanical tension and elasticity of the aorta wall. Several studies have shown that hypertension. diabetes. atherosclerosis. Marfan syndrome. smoking and aging increase aortic stiffness. Aortic elasticity is closely associated with cardiovascular mortality [10]. Aortic distensibility (AD) and aortic strain (AS) constitute the elastic properties of the aorta and reflect aortic stiffness [11.12]. The evaluation of the mechanical properties of the aorta by non-invasive method provide great benefits for the early diagnosis of atheroma [13] and increased aortic stiffness or decreased distensibility are widely used as an indicator of atherosclerotic involvement of the vascular system [14]. The objective of our study is to determine aortic stiffness parameters by means of transthoracic echocardiography in subclinical hypothyroidism patients and compare them with the group with normal thyroid function tests.

\section{Patients and Methods}

A total of 38 newly diagnosed patients with subclinical hypothyroidism admitted to the internal medicine outpatient clinics of Haydarpasa Numune Training and Research Hospital and a control group consisting of 20 healthy people with normal thyroid function tests were included in this prospective study.

Patients with history of hypertension. diabetes mellitus. hyperlipidemia. a history of acute coronary syndrome in the last six months. heart valve disease. congenital heart disease. left ventricular dysfunction (left ventricular ejection fraction $<50 \%$ ). inflammatory disease. kidney and liver disease. use of drugs that affect thyroid hormone levels (propylthiouracil. methimazole. glucocorticoids. lithium. amiodarone. propranolol. radioiodine therapy). hypothyroidism and hyperthyroidism history. thyroid surgery. undergoing pregnancy. pituitary and hypothalamic disease. a history coronary artery disease or a positive exercise electrocardiography or positive perfusion test. arrhythmia. aortic vascular disease. hypertrophic cardiomyopathy. malignancy. congestive heart failure. previous history of stroke. intermittent claudication. chronic obstructive pulmonary disease. smoking. use of oral contraceptives or estrogen replacement therapy. and with insufficient echocardiography image were excluded from the study.

All patients were informed about the study and informed consent was obtained from them. The study was approved by the local ethics committee.

The normal range of thyroid function tests and thyroid stimulating hormone (TSH) in our center were as follows: 0.27 to $4.20 \mathrm{IU} / \mathrm{ml}$ for TSH. 1.80 to $4.60 \mathrm{pg} / \mathrm{ml}$ for free T3 (FT3) and 0.93 to $1.70 \mathrm{ng} / \mathrm{dl}$ for free T4 (FT4). SCH was defined as a value of TSH> $4.94 \mathrm{IU} / \mathrm{mL}$. with normal free hormone levels. Blood samples after 12 hours of fasting were collected from all cases and total cholesterol $(\mathrm{mg} / \mathrm{dL})$. triglycerides $(\mathrm{mg} / \mathrm{dL})$. high density lipoprotein cholesterol (HDL-cholesterol) (mg / dL). low density lipoprotein cholesterol (LDL-cholesterol) (mg / dl). serum TSH (IU / $\mathrm{ml})$. FT3 (pg / ml). FT4 (ng / dl). alanine aminotransferase $($ ALT) $(\mathrm{U} / \mathrm{L})$. aspartame aminotransferase (AST) $(\mathrm{U} / \mathrm{L})$ and creatine kinase $(\mathrm{mg} / \mathrm{dl})$ were measured. The measurement of the parameters was performed in the central biochemistry laboratory of Haydarpasa Numune Training and Research Hospital. using "Roche Modular System E-170" (Japan) device. The height and weight of the patient was measured and body mass index (BMI) was calculated as the ratio of weight to height squared $\left(\mathrm{kg} / \mathrm{m}^{2}\right)$. The patients' blood pressure was measured with sphygmomanometer before the echocardiography.

\section{Transthoracic echocardiography}

Transthoracic echocardiography examination by ESAOTE 7000 CFM color Doppler echocardiography device and using 2.5-3.5 MHz transducer 78 was performed to all the cases in the patients and the control group in left lateral decubitus position. All echocardiographic measurements were carried out in three consecutive cycles and their average was taken. M-mode recordings were performed with $50 \mathrm{~mm} / \mathrm{sec}$ and the Doppler recordings with $100 \mathrm{~mm} / \mathrm{sec}$ velocity. M-mode measurements and conventional Doppler measurements. deceleration time (DT). isovolumetric relaxation time (IVRT). mitral early diastolic flow time (E). mitral late diastolic flow time (A) transmitral flow velocity ratio (E / A) were performed according to the American Echocardiography Society proposals [15]. In order to calculate aortic tension and distensibility. systolic 
and diastolic diameters of the ascending aorta was measured with M-mode echocardiography approximately $3 \mathrm{~cm}$ above the aortic valve in parasternal long axis [16]. The systolic diameter of the aorta was measured at the point of maximum forward movement of the aorta and the diastolic diameter was measured on the area corresponding to the peak of the QRS complex in the electrocardiogram. Measurements were repeated during three cardiac beats and the average value was taken.

Calculation of aortic elasticity parameters: as the aortic elasticity parameters aortic strain. the beta index and distensibility [17] were included. The following formulas were used in the calculation of the parameters:

Aortic Strain $(\%)=$ (systolic diameters - diastolic diameter) x $100 /$ diastolic diameter

Beta index $=$ IN (systolic / diastolic pressure) / aortic strain

Distensibility $\left(\mathrm{cm}^{2} /\right.$ dyne -1$)=2$ (aortic strain) $/($ systolic pressure-diastolic pressure)

\section{Statistical evaluation}

For statistical analysis of the results obtained in the study SPSS Statistical Package for Social Sciences (SPSS) for Windows 10.0 program was used. When evaluating the studys' data in addition to descriptive statistical methods. (mean. standard deviation) for the comparison of quantitative parameters with normal distribution Student's t test was used and comparison of parameters without normal distribution Mann-Whitney U test was used. Pearson correlation test was used to examine the relationship between parameters. Results were evaluated in the $95 \%$ confidence interval and $\mathrm{p}<0.05$ level.

\section{Results}

A total of 38 patients diagnosed with subclinical hypothyroidism and 20 people with normal thyroid function tests and lipid profile were enrolled in the study group. Normal distribution of age and gender groups was established between groups. The mean age of the patients was $41.29 \pm 12.82$ years. Among 38 patients with subclinical hypothyroidism 8 were men (20\%) and 30 women $(80 \%)$ and out of 20 cases in the control group 4 were men $(20 \%)$ and 16 women (80\%). respectively. There was no statistically significant difference between the groups in terms of age $(p<0.05)$. The average level of aortic strain and distensibility of the $\mathrm{SCH}$ group was found significantly lower compared to the control group $(\mathrm{p}<0.01)$ (Table I). A significant difference was found between $\mathrm{SCH}$ patients and control group in terms of aortic strain $(5.79 \%$ vs. $9.45 \% \mathrm{p}$ $<0.001$ ) and distensibility (4.64 versus 3.02 10-3.cm2.dyn1. $\mathrm{p}<0.005)$. In the subclinical hypothyroidism group the average mitral early diastolic velocity $(\mathrm{E}) .(\mathrm{P}<0.05)$ were significantly lower than the mean mitral diastolic flow velocity / mitral late diastolic flow velocity $(\mathrm{E} / \mathrm{A})(\mathrm{p}<0.01)$ observed in the control group. and higher than the mean mitral late diastolic flow velocity (A) and isovolumetric relaxation time (IVRT) $(\mathrm{p}<0.05)$ in the control group. (Table II).

Table I. The findings of aortic strain and distensibility in the control and subclinical hypothyroid group

\begin{tabular}{lcll}
\hline & $\begin{array}{c}\text { SCH group } \\
(\mathbf{n}=\mathbf{3 8})\end{array}$ & $\begin{array}{c}\text { Control group } \\
(\mathbf{n}=\mathbf{2 0})\end{array}$ & \\
\hline Aortic strain (\%) & $5.79 \pm 4.10$ & $9.45 \pm 3.24$ & $\mathrm{t}:-3.454$ \\
& & & $\mathrm{p}: 0.001^{* *}$ \\
& & & $\mathrm{t}:-2.898 ;$ \\
Distensibility & $3.02 \pm 2.25$ & $4.64 \pm 1.50$ & $\mathrm{p}: 0.005^{* *}$ \\
\hline
\end{tabular}

**p value of $p<0.01$ was considered as statistically significant. $t$ : Student's t test SCH: Subclinical hypothyroidism

Table II. The clinical and echocardiographic findings in SCH and control

\begin{tabular}{|c|c|c|c|}
\hline & SCH $(n=38)$ & Control $(n=20)$ & \\
\hline Age (year) & $42 \pm 15$ & $38 \pm 6$ & $\mathrm{t}: 1.533 ; \mathrm{p}: 0.131$ \\
\hline $\mathrm{E}(\mathrm{m} / \mathrm{s})$ & $7.18 \pm 2.32$ & $8.30 \pm 1.26$ & $\begin{array}{l}\text { t:-1.993; } \\
\text { p:0.050* }\end{array}$ \\
\hline $\mathrm{A}(\mathrm{m} / \mathrm{s})$ & $6.68 \pm 2.34$ & $6.20 \pm 1.15$ & $\begin{array}{l}\mathrm{U}: 255.5 \\
\mathrm{P}: 0.037^{*}\end{array}$ \\
\hline $\mathrm{E} / \mathrm{A}$ & $10.05 \pm 4.12$ & $13.95 \pm 4.47$ & $\begin{array}{l}\text { t:-3.327; } \\
\text { p:0.002** }\end{array}$ \\
\hline IVRZ(ms) & $102.89 \pm 29.90$ & $88.15 \pm 19.73$ & $\begin{array}{l}\mathrm{t}: 1.985 \\
\mathrm{p}: 0.050^{*}\end{array}$ \\
\hline $\mathrm{DT}(\mathrm{ms})$ & $159.55 \pm 42.84$ & $147.65 \pm 35.97$ & $\mathrm{t}: 1.060 ; \mathrm{p}: 0.294$ \\
\hline $\mathrm{ASD}(\mathrm{mm})$ & $28.82 \pm 3.96$ & $29.19 \pm 4.47$ & t:-0.320; p:0.750 \\
\hline $\mathrm{ADD}(\mathrm{mm})$ & $26.14 \pm 4.08$ & $25.88 \pm 4.38$ & $\begin{array}{l}\text { U:354.5; } \\
\text { P:0.676 }\end{array}$ \\
\hline TSH( $\mu \mathrm{IU} / \mathrm{ml})$ & $7.78 \pm 2.60$ & $2.30 \pm 0.81$ & $\begin{array}{l}\mathrm{t}: 11.919 \\
\mathrm{p}: 0.001^{* *}\end{array}$ \\
\hline
\end{tabular}

$* p$ value of $p<0.05$ was considered as statistically significant

** $p$ value $p<0.01$ was considered as statistically significant

$\boldsymbol{t}$ : Student's $t$ test. $\boldsymbol{U}$ : Mann Whitney $U$ test.

SCH: subclinical hypothyroidism. $\boldsymbol{E}$ : mitral early diastolic velocity (E). A: mitral late diastolic flow velocity (A). E/A: mitral early diastolic velocity / mitral late diastolic flow velocity (E / A). IVRZ: isovolumetric relaxation time. DT: deceleration time. ASD: systolic diameters $\boldsymbol{A D D}$ : diastolic diameter. $\mathbf{T S H}$ : thyroid stimulating hormone 
A $47.6 \%$. statistically significant negative correlation was found between age and distensibility $(p<0.01)$. A statistically significant positive correlation of $37.1 \%$ was found between $E$ and distensibility $(p<0.05)$. A statistically significant relationship between distensibility and A. E / A was found $(p>0.05)$. A statistically significant negative correlation of $43.2 \%$ was found between distensibility and IVRT $(\mathrm{p}<0.01)$. A statistically significant negative relationship between distensibility and DT delay time (DT) of $39.7 \%$ was found ( $p<0.05$ ). No statistically significant correlation between distensibility and ASD. ADD and TSH levels was found $(\mathrm{p}>0.05)$. A positive statistically significant correlation between FT3 and distensibility. at the level of $34.5 \%$ was found $(\mathrm{p}<0.05)$. There was no statistically significant relation between distensibility and $\mathrm{s}$ T4 ( $\mathrm{p}>0.05)$ (Table III).

Table III. Correlations of distensibility

\begin{tabular}{lll}
\hline & \multicolumn{2}{c}{ Distensibility } \\
\cline { 2 - 3 } & $\mathrm{r}$ & $\mathrm{p}$ \\
\hline Age (year) & -0.476 & $0.003^{* *}$ \\
Aortic Strain & 0.913 & $0.001^{* *}$ \\
E(m/s) & 0.371 & $0.022^{* *}$ \\
A(m/s) & 0.070 & 0.677 \\
E/A (m/s) & 0.160 & 0.336 \\
IVRZ(ms) & -0.432 & $0.007 * *$ \\
DT(ms) & -0.397 & $0.013 *$ \\
ASD (mm) & -0.160 & 0.337 \\
ADD (mm) & -0.187 & 0.262 \\
TSH( $\mu$ IU/ ml) & -0.224 & 0.176 \\
\hline
\end{tabular}

* $p$ value of $p<0.05$ was considered as statistically significant

$*_{*}^{*} p$ value $p<0.01$ was considered as statistically significant

$r$ : Pearson correlation coefficient

SCH: subclinical hypothyroidism. E: mitral early diastolic velocity (E). A: mitral late diastolic flow velocity (A). $\boldsymbol{E} / \boldsymbol{A}$ : mitral early diastolic velocity / mitral late diastolic flow velocity (E / A). IVRZ: isovolumetric relaxation time. DT: deceleration time. ASD: systolic diameters $\boldsymbol{A D D}$ : diastolic diameter. TSH: thyroid stimulating hormone

\section{Discussion}

The results of this study indicated that in patients with subclinical hypothyroidism. through the transthoracic echocardiography. which is a noninvasive diagnostic method. the aortic distensibility. which is the indicative of the aortic stiffness. is decreased and the aortic stiffness is increased. and the aortic elasticity parameters are the strongest predictor of left ventricular diastolic function.

Cardiovascular system is one of the major systems affected by thyroid hormone. The most important changes observed in the cardiovascular system in patients with hypothyroidism are increased vascular resistance. diastolic dysfunction. reduction of cardiac preload and decreased systolic function [12]. In a study conducted by echocardiography. isovolumetric relaxation time was found to be longer in patients with subclinical hypothyroidism [13]. In different studies. an increase was observed in coronary artery disease and cardiovascular mortality in SCH patients [18.19]. The reduction in myocardial contractility and heart rate in $\mathrm{SCH}$ patients leads to a decreased cardiac output and exercise tolerance. In addition. in these patients an increase in the systemic vascular resistance and extracellular volume and diastolic dysfunction as a result of endothelial dysfunction develops [20]. The diastolic function in $\mathrm{SCH}$ patients was assessed by Biondi and friends for the first time with Doppler echocardiography and myocardial relaxation anomalies were found. Following 6 months thyroid replacement therapy in these patients a normalization of IVRZ and decrease of E / A ratio was found [21]. In a prospective study conducted by Niafar et al evaluating cardiac functions in $\mathrm{SCH}$ women and healthy subjects it was found that $\mathrm{SCH}$ could lead to the left ventricle diastolic dysfunction [22]. There is evidence that shows the negative effects of increased stiffness of large arteries on cardiovascular outcomes [17]. In the Framingham study. the baseline and 20 years follow up increase of pulse pressure as marker of large artery stiffness. was strongly associated with coronary artery disease risk in elderly and middle-aged population without clinical history of coronary artery disease [23].

Aortic stiffness is a predictor of all-cause mortality in cardiovascular disease independent of other risk factors such as age and diabetes. Many methods have been described in the evaluation of arterial stiffness. These techniques vary from quite a simple process such as brachial pulse pressure measurements which can be assessed by cuff to more detailed and complex techniques which may require hardware such as pulse wave velocity variables. determination of aortic impedance and aortic elastic coefficient. The measurement of pulsatile variability of the diameter of the aorta using an ultrasound catheter and invasive procedures provides information on aortic elasticity [24]. The pulsatile distensibility and variability of aorta can be assessed using a noninvasive method such as echocardiography [25]. 
Increased arterial stiffness in fact is an important indicator of vascular aging [26].

Many studies have reported that hypertension and diabetes decreased aortic strain and distensibility. How hypertension and diabetes induce an increase in aortic stiffness is not known. However. a possible mechanism; hypertension generates high pressure in the arterial wall leading to a number of structural changes and atherosclerosis. Diabetes causes the accumulation of glycosides in the arterial wall which are believed to form arteriosclerosis. Regardless. the mechanism aortic vascular stiffness is related with high mortality in patients with diabetes mellitus and hypertension [11].

The cardiovascular disease risk is more significant in clinical hypothyroidism than the SCH [27]. Some observational studies [28.29] have shown an increase risk of coronary heart disease in patients with $\mathrm{SCH}$. But the results of other studies [30.31] have shown that the increased coronary heart disease risk is not substantial. In SCH patients atherosclerosis risk factors such as hypertension. increased C-reactive protein levels. and changes in the coagulation system. endothelial dysfunction. and increased arterial stiffness and thermogenic lipid profile are also present [32] .

Dyslipidemia may cause some changes in the elasticity of the arterial wall [28]. Several studies have shown a relationship between $\mathrm{SCH}$ and atherogenic lipid profile [33.34]. When compared with euthyroid patients. elevated serum triglycerides and LDL-C levels have been reported in SCH patients [35]. In our study. in order to evaluate aortic stiffness and distensibility. transthoracic echocardiography has been performed in $38 \mathrm{SCH}$ patients and 20 patients with a normal thyroid function tests. Patients without history of factors that affects aortic stiffness such hypertension. hypercholesterolemia. diabetes. coronary artery disease. cerebrovascular disease. liver disease and renal failure have been selected. There was no statistically significant difference between the $\mathrm{SCH}$ and control group in terms of age $(\mathrm{p}>0.05)$.

We found that the non-invasive diagnostic methods aortic distensibility and aortic strain level in $\mathrm{SCH}$ patients were significantly lower than the control group. In studies conducted before it has been found that $\mathrm{SCH}$ affects left ventricular diastolic dysfunction and arterial stiffness [36.21]. Statistically. a significant negative relationship between distensibility and age and IVRT between significant positive relationship between aortic strain and $\mathrm{E}$ was found $(\mathrm{p}<0.01)$. (Table III).
In a study conducted by Mishra et al. echocardiography findings of SCH patients and control group were compared [37]. The results were similar to our study. The mean IVRZ and $\mathrm{A}$ was found higher and $\mathrm{E} / \mathrm{A}$ ratio lower in $\mathrm{SCH}$ patients respectively $(\mathrm{p}<0.05)$. After a year of hormone replacement therapy. an improvement in the left ventricular diastolic function has been found in patients with $\mathrm{SCH}$ [37]. In a study investigating the effect of low dose L-thyroxine therapy over left ventricular diastolic function in $\mathrm{SCH}$ patients. the $\mathrm{E}$ and $\mathrm{E} / \mathrm{A}$ ratio were found lower in the $\mathrm{SCH}$ patients compared to the healthy control group [38].

The positive effects of thyroid replacement therapy on arterial stiffness in patients with $\mathrm{SCH}$ have been shown in several studies. In a study evaluating myocardial reserve and arterial stiffness. arterial stiffness was observed to decrease following six months of treatment [39].

Several studies have shown that arterial stiffness is a major cause of cardiovascular complications. The presence of atherosclerotic lesions in the aortic wall may contribute to decreased elasticity of the ascending aorta. Therefore. the degradation of the arterial blood vessel elasticity can facilitate the formation of atherosclerosis [40]. In a recent study. it was reported that $\mathrm{SCH}$ associated with left ventricular diastolic dysfunction and arterial stiffness may be a risk factor for cardiovascular events [41]. In the study conducted by Yurtdaş et al. the aortic elastic features were investigated using tissue Doppler imaging; aortic distensibility in patients with SCH was statistically lower than euthyroid patients $(\mathrm{p}<0.001)$ and aortic stiffness index was significantly higher in patients with $\mathrm{SCH}(\mathrm{p}<0.001)$ [42]. In this study. similar to ours it was shown that stiffness index is high in patients with $\mathrm{SCH}$ and aortic distensibility is lower than the control group.

Masaki et al. in their study showed that $\mathrm{SCH}$ associated with left ventricle diastolic dysfunction and arterial stiffness may increase cardiovascular events [41]. In our study. the aortic strain and distensibility of $\mathrm{SCH}$ was found to be lower than the control group.

In conclusion. our study has shown that $\mathrm{SCH}$ is associated with left ventricular diastolic dysfunction and decrease in the elastic properties of the aorta. The aortic stiffness evaluated by means of echocardiography is increased in patients with $\mathrm{SCH}$. An indicator of early vascular aging. arterial stiffness. can be easily measured by non-invasive transthoracic echocardiography. It is a method that can be easily assessed and provide more intensive treatment of risk factors therefore reducing cardiovascular diseases and 
mortality. The reduction of the elastic properties of the aorta may play a causal role in the development of increased afterload and left ventricle diastolic dysfunction. The aortic elasticity parameters measured by non-invasive methods may be useful in early prevention and prediction of the risk of cardiovascular disease. However. prospective studies with more patients are needed.

\section{Limitations of the study}

The small number of SCH patients and control group and the lack of TSH levels or subgroup analysis are the main potential limitation to our study. Therefore. long-term prospective studies including a larger number of patients are needed.

\section{References}

1. Surks MI. Ortiz E. Daniels GH. et al. Subclinical thyroid disease: scientific review and guidelines for diagnosis and management. JAMA. 2004; 291:228-38. doi: 10.1001/ jama.291.2.228.

2. Canaris GJ. Monowitz NR. Mayor G. et al. The Colorado thyroid disease prevalence study. Arch Intern Med 2000; 160:526-34.doi: 10.1001/archinte.160.4.526.

3. Hollowell JG. Staehling NW. Flanders WD. et al. Serum TSH. T4 and thyroid antibodies in the United States population (1988 to 1994): National Health and Nutrition Examination Survey ( NHANES III). J Clin Endocrinol Metab 2002; 87: 489-99.

4. Biondi B. Cooper DS. The clinical significance of subclinical thyroid dysfunction. Endocr Rev 2008; 29:76-131. doi: http:// dx.doi.org/10.1210/er.2006-0043.

5. Hak AE. Pols HA. Visser TJ. et al. Subclinical hypothyroidism is an independent risk factor for atherosclerosis and myocardial infarction in elderly women: the Rotterdam Study. Ann Intern Med 2000; 132:270-8. doi:10.7326/00034819-132-4-20002150-00030

6. Cappola AR. Razvi S. Walsh JP. et al. Subclinical hypothyroidism and the risk of coronary heart disease and mortality. JAMA 2010 ; 304: 1365-74. doi: 10.1001/ jama.2010.1361.

7. Walsh JP. Bremner AP. Bulsara MK. et al. Subclinical thyroid dysfunction as a risk factor for cardiovascular disease. Arch Intern Med 2005; 165 : 2467-72. doi:10.1001/ archinte.165.21.2467.

8. Vaderpump MP. Tunbridge WM. French JM. et al. The development of schemic heart disease in relation to autoimmune thyroid disease in a 20- year follow-up study of an English community. Thyroid 1996; 6: 155-60.

9. Schultz M. Kistorp C. Raymond I. et al. Cardiovascular events in thyroid disease: A population based. prospective study. Horm Metab Res 2011; 43: 653-9. doi: 10.1055/s-00311283162.

10. Stefanadis C. Wooley CF. Bush CA. Kolibash AL. Boudoulas $\mathrm{J}$. Aortic distensibility anormalities in coronary artery disease.
Am J Cardiol 1987; 59:1300-4

11. Eren M. Gorgulu Ş. Uslu N. Celik S. Dağdeviren B. Tezel T. Relation between aortic stiffness and left ventricular diastolic function in patients with hypertension . diabetes. or both. Heart 2001;90:37-43. doi: 10.1136/heart.90.1.37

12. Ikonomidis I. Lekakis J. Stamatelopoulos K. et al. Aortic elastic properties and left ventricular diastolic function in patients with Adamantiades-Behcet's Disease. J Am Coll Cardiol 2004; 43: 1075-81.doi:10.1016/j.jacc.2003.10.042

13. Lacombe F. Dart A. Dewar E. et al. Arterial elastic properties in man: a comparison of echo-Doppler indices of aortic stiffness. Eur Heart J 1992. 13: 1040-5. doi:http://dx.doi. org/1040-1045.

14. Nicole M. Van Popole MD. Diederick E. Association between arterial stiffness and atherosclerosis. The Rotterdam Study. Stroke 2001;32:454-60. doi:10.1161/01.STR.32.2.454

15. Cheitlin MD. Alpert JS. Armstrong WF. et al. ACC/AHA guidelines for the clinical application of echocardiography. A report of the American College of Cardiology /American Heart Association Task Force on Practice Guidelines (Committee on Clinical Application of Echocardiography). Developed in collaboration with the American Society of Echocardiography. Circulation 1997; 95: 1686-744. 253 . doi: 10.1161/01.CIR.95.6.1686.

16. Stratos C. Stefanadis C. Kallikazaros I.et al. Ascending Aorta distensibility abnormalities in hypertensive patients and response to nifedipine administration.Am J Med 1992; 93:505-12. doi:http://dx.doi.org/10.1016/0002-9343(92) 90577-X

17. Laurent S. Boutouyrie P. Asmar R. et al. Aortic stiffness is an indepent predictor of all-cause and cardiovascular mortality in hypertensive patients. Hypertension. 2001; 37: 1236-41. doi:10.1161/01.HYTP.37.5.1236

18. Ochs N. Auer R. Bauer DC. et al. Meta-analysis: subclinical thyroid dysfunction and the risk for coronary heart disease and mortality. Ann Intern Med. 2008;148:832-45. doi:10.7326/0003-4819-148-11-200806030-00225

19. Imaizumi M. Akahoshi M. Ichimaru S. et al. Risk for ischemic heart disease and all-cause mortality in subclinical hypothyroidism. J Clin Endocrinol Metab. 2004;89:3365-70. doi:10.1210/jc.2003-031089

20. Devdhar M. Ousman YH. Burman KD. Hypothyroidism. Endocrin Metab Clin.North Am. 2007; 36: 595-615. doi:10.1016/j.ecl.2007.04.008

21. Biondi B. Fazio S. Palmieri EA. et al. Left ventricular diastolic dysfunction in patients with subclinical hypothyroidism. J Clin. Endocrinol Metab 1999; 84:2064-7.

22. Niafar M. Tofan M. Ghafoori S. et al. Subclinical hypothyroidism effects on cardiac function. Pak J Biol Sci. 2009; 12:1056-62.

23. Franklin SS. Khan SA. Wong ND.et al. Is pulse pressure useful in predicting risk for coronary heart disease? The Framingham Heart Study. Circulation 1999; 100:354-60. doi:10.1161/01.CIR.100.4.354

24. Stefanadis C. Dernellis J. Vlachopoulos C. et al. Aortic function in arterial hypertension determined by pressurediameter relation: effects of diltiazem. Circulation 1997; 96:1853-8.doi: 10.1161/01.CIR.96.6.1853

25. Lacombe F. Dart A. Dewar E. et al.Arterial elastic properties 
in man: a comparison of echo-Doppler indices of aortic stiffness. Eur Heart J1992; 13: 1040- 5. doi: http://dx.doi. org/1040-1045.

26. Stehourwer CD. Henry RM. Ferreira I. Arterial stiffness in diabetes and the metabolic syndrome: a pathway to cardiiovascular disease. Diabetologia 2008; 51: 527-39. doi:10.1007/s00125-007-0918-3.

27. Lideman RD. Romero LJ. Schade DS.etal. Impact of subclinical hypothyroidism on serum total homocysteine concentrations. the prevalence of coronary heart disease (CHD). and CHD risk factors in the New Mexico Elder Health Survey. Thyroid 2003;13:595-600. doi:10.1089/105072503322238863.

28. Plana N. Ferre R. Merinos J. et al. Heterozygous familial hypercholesterolaemic patients have increased stiffness. as determined using the augmentation Index. J Atheroscler Thromb 2011; 18: 1110-6. doi: http://doi.org/10.5551/ jat.9795.

29. Ravzi S. Weaver JU. Vanderpump MP. et al. The incidence of ischemic heart disease and mortality in people with subclinical hypothyroidism : Reanalysis of the Whickham Surver cohort. J Clin Endocrinol Metab 2010; 95: 1734-40. doi:10.1210/ jc.2009-1749.

30. Rodondi N. Bauer DC. Cappola AR. et al. Subclinical thyroid dysfunction. cardiac function. and the risk of heart failure. The Cardiovascular Health study. J Am Coll Cardiol 2008; 52: 1152-9. doi:10.1016/j.jacc.2008.07.009.

31. Rodondi N. den Elzen WP. Barer DC. et al. Thyroid Studies Collaboration. Subclinical hypothroidism and the risk of coronary heart disaese and mortality. JAMA 2010; 304: 136574.

32. Biondi B. Klein I. Hypothyroidism as a risk factor for cardiovascular disease. Endocrin2004; 24: 1-13.

33. Duntas LH. Mantzou E. Koutras DA. Circulating levels of oxidized low-density lipoprotein in overt and mild hypothyroidism. Thyroid 2002;12:1003-7. doi:10.1089/105072502320908349.

34. Gen R. Akbay E. Sezer K.et al. Insulın resistance and cardiovascular risk factors in patients with mild severe subclinical hypothyroidism. Endocrinologist 2010; 20: 12830. doi:http://dx.doi.org/10.1097/TEN.Ob013e3181dfe618.

35. Dardano A. Ghiadoni L. Plantinga Y. et al. Recombinant human thyrotropin reduced endothelium-dependent vasodilation in patients monitored for differentiated thyroid carcinoma. J Clin Endocrinol Metab 2006;91:4175-8. doi:http://dx.doi. org/10.1210/jc.2006-0440.

36. Nagasaki T. Inaba M. Kumeda Y. et al. Increased pulse wave velocity in subclinical hypothyroidism. J Clin Endocrinol Metab 2006; 91: 154-158. doi:http://dx.doi.org/10.1210/ jc.2005-1342.

37. Mishra TK. Routray SN. Das S.et al. Left ventricular dysfunction in patients with subclinical hypothyroidism and its reversibility after hormone therapy. J Assoc Physicians India 2005; 53:943-6.

38. Shatynska-Mytsyk I. Rodrigo L. Cioccocioppo R.et al. The impact of thyroid hormone replacement therapy on left ventricular diastolic function in patients with subclinical hypothyroidism. J Endocrinol Invest 2015 mar 5. doi: 10.1007//s40618-015-0262-2.

39. Owen PJ. Rajiv C. Vinereanu D. et al.Subclinial hypothyroidism. arterial stiffness and myocardial reserve. J Clin Endocrinol Metab. 2006; 91:2126-32.doi:http://dx.doi. org/10.1210/jc.2005-2108

40. Malayeri AA. Natori S. Bahrami H. et al. Relation of aortic wall thickness and distensibility to cardiovascular risk factors. Am J Cardiol 2008; 102:491-6.doi:10.1016/j. amjcard.2008.04.010.

41. Masaki M. Komamura K. Goda A. et al. Elevated arterial stiffness and diastolic dysfunction in subclinical hypothyroidism. Circulation Journal 2014; 78: 1494-1500. doi:http://doi.org/10.1253/circj.CJ-13-1556.

42. Yurtdaş M. Gen R. Özcan T.et al. Assessment of the elasticity properties of the ascending aorta in patients with subclinical hypothyroidism by tissue Doppler imaging. Arq Bras Endocrinol Metab 2013; 57 : 132-8.doi:http://dx.doi. org/10.1590/S0004-27302013000200006. 